\title{
COVID-19 pandemic and distinct patterns of psychotic outbreaks
}

There is concern about the impact of the coronavirus disease 2019 (COVID-19) pandemic on mental health and, more specifically, on the incidence of psychotic disorders. However, limited evidence is available to examine predictions and to plan preventive measures. ${ }^{1}$

We reviewed the clinical data of patients diagnosed with a psychotic disorder and presenting a chief complaint related to the COVID-19 pandemic. All patients were evaluated at the psychiatric emergency unit of Universidade Federal de São Paulo (UNIFESP), between March and August 2020, in São Paulo, Brazil. Confidentiality of all subjects was preserved, and the study was approved by the research ethics committee of the UNIFESP (CAAE 33124620.0.0000.5505). Sociodemographic characteristics, clinical features, diagnostic hypotheses, and complementary information are presented in Table 1.

Table 1 - Sociodemographic and clinical characteristics

\begin{tabular}{|c|c|c|c|c|c|c|}
\hline & Case A & Case B & Case C & Case D & Case E & Case F \\
\hline \multicolumn{7}{|l|}{ Sociodemographic characteristics } \\
\hline Age & 26 & 45 & 48 & 11 & 65 & 34 \\
\hline Gender & Female & Female & Male & Female & Female & Female \\
\hline Marital status & Single & Unavailable & Single & Single & Married & Single \\
\hline Education & Higher & Primary & Higher & Primary & Unavailable & Unavailable \\
\hline \multicolumn{7}{|l|}{ Psychopathology } \\
\hline Delusions & Yes & Yes & Yes & Yes & Yes & Yes \\
\hline Hallucinations & No & No & Yes & No & No & No \\
\hline $\begin{array}{l}\text { Agitated or disorganized } \\
\text { behavior }\end{array}$ & Yes & No & Yes & Yes & No & Yes \\
\hline $\begin{array}{l}\text { Clinical history related to } \\
\text { COVID-19 pandemic }\end{array}$ & $\begin{array}{l}\text { Patient said } \\
\text { she could cure } \\
\text { COVID-19 and } \\
\text { mentioned that } \\
\text { the virus was the } \\
\text { apocalypse }\end{array}$ & $\begin{array}{l}\text { Patient believed } \\
\text { that her neighbors } \\
\text { had passed } \\
\text { information about } \\
\text { her COVID-19 } \\
\text { infection to the } \\
\text { government }\end{array}$ & $\begin{array}{l}\text { Patient presented } \\
\text { fixed idea of being } \\
\text { infected with the } \\
\text { virus, evolving } \\
\text { with episodes of } \\
\text { agitation }\end{array}$ & $\begin{array}{l}\text { Excessive fear } \\
\text { of COVID-19, } \\
\text { asking for silence } \\
\text { at home, so that } \\
\text { neighbors could } \\
\text { not hear her } \\
\text { family }\end{array}$ & $\begin{array}{l}\text { Patient said } \\
\text { that everyone } \\
\text { would die from } \\
\text { COVID-19 and } \\
\text { reported that the } \\
\text { coronavirus came } \\
\text { out of her urine }\end{array}$ & $\begin{array}{l}\text { Patient } \\
\text { repeatedly said } \\
\text { the coronavirus } \\
\text { would catch } \\
\text { her, presenting } \\
\text { disorganized } \\
\text { behavior }\end{array}$ \\
\hline \multicolumn{7}{|l|}{ Clinical features } \\
\hline History of psychotic symptoms & No & No & No & No & $\begin{array}{l}\text { Yes ( } 1 \text { previous } \\
\text { episode) }\end{array}$ & $\begin{array}{l}\text { Yes ( } 1 \text { previous } \\
\text { episode) }\end{array}$ \\
\hline History of psychiatric treatment & Yes & No & No & No & Yes & Yes \\
\hline History of substance use & Alcohol & No & Alcohol & No & No & No \\
\hline $\begin{array}{l}\text { Family history of mental } \\
\text { disorders }\end{array}$ & Yes & Yes & No & No & Yes & Yes \\
\hline Previous COVID-19 infection & No & Yes & No & No & No & No \\
\hline Diagnostic hypothesis* & Bipolar I disorder & $\begin{array}{l}\text { Brief psychotic } \\
\text { disorder }\end{array}$ & $\begin{array}{l}\text { Brief psychotic } \\
\text { disorder }\end{array}$ & $\begin{array}{l}\text { Brief psychotic } \\
\text { disorder }\end{array}$ & $\begin{array}{l}\text { Brief psychotic } \\
\text { disorder }\end{array}$ & Schizophrenia \\
\hline Suicidal ideation or behavior & No & No & Yes & No & No & No \\
\hline
\end{tabular}


Table 1 (cont.)

\begin{tabular}{|c|c|c|c|c|c|c|}
\hline & Case G & Case $\mathbf{H}$ & Case I & Case $\mathbf{J}$ & Case $\mathrm{K}$ & Case L \\
\hline \multicolumn{7}{|l|}{ Sociodemographic characteristics } \\
\hline Age & 21 & 58 & 57 & 45 & 26 & 43 \\
\hline Gender & Male & Male & Female & Female & Female & Male \\
\hline Marital status & Single & Single & Married & Single & Single & Married \\
\hline Education & Secondary & Higher & Unavailable & Higher & Secondary & Primary \\
\hline \multicolumn{7}{|l|}{ Psychopathology } \\
\hline Delusions & Yes & Yes & Yes & Yes & Yes & Yes \\
\hline Hallucinations & Yes & No & Yes & No & Yes & Yes \\
\hline $\begin{array}{l}\text { Agitated or disorganized } \\
\text { behavior }\end{array}$ & Yes & Yes & Yes & Yes & Yes & Yes \\
\hline $\begin{array}{l}\text { Clinical history related to } \\
\text { COVID-19 pandemic }\end{array}$ & $\begin{array}{l}\text { Patient said he } \\
\text { had influenced } \\
\text { God and Lucifer } \\
\text { to start the } \\
\text { COVID } 19 \\
\text { pandemic }\end{array}$ & $\begin{array}{l}\text { Patient presented } \\
\text { delusions about } \\
\text { the end of } \\
\text { the world by } \\
\text { the COVID-19 } \\
\text { pandemic }\end{array}$ & $\begin{array}{l}\text { Patient felt guilty } \\
\text { for creating } \\
\text { the COVID-19 } \\
\text { pandemic }\end{array}$ & $\begin{array}{l}\text { Patient claimed to } \\
\text { have the cure for } \\
\text { coronavirus, and } \\
\text { that she could } \\
\text { end the covID-19 } \\
\text { pandemic }\end{array}$ & $\begin{array}{l}\text { Patient stated that } \\
\text { the coronavirus } \\
\text { meant the end of } \\
\text { the world and that } \\
\text { God was returning }\end{array}$ & $\begin{array}{l}\text { Patient said he } \\
\text { was sent by God } \\
\text { to help in the } \\
\text { pandemic and } \\
\text { that he had the } \\
\text { gift of healing }\end{array}$ \\
\hline \multicolumn{7}{|l|}{ Clinical features } \\
\hline History of psychotic symptoms & $\begin{array}{l}\text { Yes (multiple } \\
\text { episodes) }\end{array}$ & $\begin{array}{l}\text { Yes (multiple } \\
\text { episodes) }\end{array}$ & $\begin{array}{l}\text { Yes (multiple } \\
\text { episodes) }\end{array}$ & $\begin{array}{l}\text { Yes (multiple } \\
\text { episodes) }\end{array}$ & $\begin{array}{l}\text { Yes (multiple } \\
\text { episodes) }\end{array}$ & $\begin{array}{l}\text { Yes (multiple } \\
\text { episodes) }\end{array}$ \\
\hline History of psychiatric treatment & Yes & Yes & Yes & Yes & Yes & Yes \\
\hline History of substance use & Cannabis/Cocaine & Unavailable & No & No & No & No \\
\hline $\begin{array}{l}\text { Family history of mental } \\
\text { disorders }\end{array}$ & No & Unavailable & Yes & No & No & Yes \\
\hline Previous COVID-19 infection & No & No & No & No & No & No \\
\hline Diagnostic hypothesis* & Schizophrenia & Bipolar I disorder & Schizophrenia & Bipolar I disorder & Schizophrenia & Bipolar I disorder \\
\hline Suicidal ideation or behavior & No & No & Yes & No & No & No \\
\hline Need for psychiatry hospitalization & Yes & Yes & Yes & Yes & Yes & Yes \\
\hline
\end{tabular}

COVID-19 = coronavirus disease 2019

* According to the Diagnostic and Statistical Manual of Mental Disorders, 5th edition (DSM-5). ${ }^{2}$

Of 12 individuals, 4 (33.3\%) presented new-onset psychosis, while 8 had a previous history of psychotic symptoms. Among new-onset patients, the diagnosis of brief psychotic disorder, according to the Diagnostic and Statistical Manual of Mental Disorders, 5th edition $(\mathrm{DSM}-5){ }^{2}$ was the most prevalent one $(75 \%)$. Eight patients $(66.6 \%)$ were hospitalized due to severe psychomotor agitation and/or suicidal ideation. Seven of them received a diagnosis of schizophrenia or bipolar I disorder and one received a diagnosis of brief psychotic disorder. All cases presented delusions or hallucinations with content related to the pandemic.

Psychotic symptoms can be understood as a cognitive scheme developed to explain an aberrant salience experience, ${ }^{3}$ and they commonly incorporate external (recent or stressful) events, ${ }^{4}$ such as the COVID-19 pandemic. Psychosis may emerge via two non-competing pathways in the context of the pandemic. First, there is the psychological distress leading to brief psychotic reactions or anticipating disease onset/ relapse in those more genetically vulnerable. Second, psychosis may be a result of the direct effect of the viral infection on the brain, including post-viral presentations and treatment-related complications such as steroidinduced psychosis. ${ }^{5}$

Only one individual had a history of COVID-19 infection, but there were no signs of clinical impairment related to viral infection or complications. Three out of four patients with new-onset psychosis did not present prodromal features of psychotic disorders, i.e., they presented delusion but neither gross disorganization nor negative symptoms. Also, these patients had an atypical age of onset for first-episode psychosis, ${ }^{6}$ and presented lower psychiatric risks or need for hospitalization, as opposed to patients with a previous history of psychotic symptoms. Such features suggest a more benign evolution and demand closer follow-up to define the need to maintain antipsychotic treatment and titration, avoiding unnecessary harm due to treatment. ${ }^{7}$

In conclusion, we observed two patterns of psychotic disorders related to the psychological distress caused by the COVID-19 pandemic: 1) brief, apparently mild newonset cases; and 2) relapse of previously diagnosed patients. The reduced number of cases directly 
associated with viral infection can be explained by the study design, which included patients who directly sought psychiatric care. Moreover, it can suggest that psychological distress represents a higher burden to psychotic outcomes amid the COVID-19 pandemic, but this needs to be addressed in larger, representative samples. Further epidemiological studies are needed to assess a possible increased risk for psychotic disorders related to the pandemic, and follow-up studies can help to better understand the evolution and clinical outcome of the related disorder.

\section{Carlos Gustavo Costardi, ${ }^{1}$ (D) Daniel A. Cavalcante, ${ }^{1,2}$ Marcos Antônio Macêdo, ${ }^{1}$ Raphael de O. Cerqueira, ${ }^{1}$ Maria Carolina Rios, ${ }^{1}$ Cristiano Noto, ${ }^{1,2,3,4}$ Ary Gadelha $\mathbf{a}^{1,2,3,4}$ (i)}

1 Laboratório Interdisciplinar de Neurociências Clínicas (LiNC), Escola Paulista de Medicina - Universidade Federal de São Paulo (EPM-UNIFESP), São Paulo, SP, Brazil. ${ }^{2}$ Grupo de Atenção às Psicoses Iniciais (GAPi), Departamento de Psiquiatria, EPMUNIFESP, São Paulo, SP, Brazil. ${ }^{3}$ Programa de Esquizofrenia (PROESQ), Departamento de Psiquiatria, EPM-UNIFESP, São Paulo, SP, Brazil. ${ }^{4}$ Centro de Pesquisa e Inovação em Prevenção de Transtornos Mentais e Uso de Álcool e Outras Drogas (CEPIPREV), EPM-UNIFESP, São Paulo, SP, Brazil.

Submitted Dec 17 2020, accepted for publication Jan 272021.

\section{Acknowledgements}

The authors would like to thank the resident doctors of the Department of Psychiatry at Universidade Federal de São Paulo, Andrew Miguel, Beatriz Pereira and Guilherme Resende, for their collaboration in the study.

\section{Disclosure}

Carlos Gustavo Costardi has served as a consultant and/or advisor to or has received honoraria from Aché and Cristália. Daniel A. Cavalcante has served as a consultant and/or advisor to or has received honoraria from Lundbeck, Aché, and Torrent. Cristiano Noto has served as a consultant and/or advisor to or has received honoraria from Daiichi-Sankyo and Janssen. Ary Gadelha has served as a consultant and/or advisor to or has received honoraria from Ache, Daiichi-Sankyo, Torrent, Cristália, and Janssen. The other authors report no conflicts of interest.

Suggested citation: Costardi CG, Cavalcante DA, Macêdo MA, Cerqueira RO, Rios MC, Noto C, et al. COVID-19 pandemic and distinct patterns of psychotic outbreaks. Trends Psychiatry Psychother. 2021;43(4):337-337. http://dx.doi.org/10.47626/2237-6089-2020-0188

\section{References}

1. Brown E, Gray R, Lo Monaco S, O'Donoghue B, Nelson B, Thompson $A$, et al. The potential impact of COVID-19 on psychosis: a rapid review of contemporary epidemic and pandemic research. Schizophr Res. 2020;222:79-87.

2. American Psychiatric Association. Diagnostic and Statistical Manual of Mental Disorders, Fifth Edition (DSM-5). Arlington: American Psychiatric Publishing; 2013.

3. Kapur S, Mizrahi R, Li M. From dopamine to salience to psychosislinking biology, pharmacology and phenomenology of psychosis. Schizophr Res. 2005;79:59-68.

4. Ovejero S, Baca-García E, Barrigón ML. Coronovirus infection as a novel delusional topic. Schizophr Res. 2020;222:541-2.

5. Rogers JP, Chesney E, Oliver D, Pollak TA, McGuire P, Fusar-Pol $P$, et al. Psychiatric and neuropsychiatric presentations associated with severe coronavirus infections: a systematic review and meta-analysis with comparison to the COVID-19 pandemic. Lancet Psychiatry. 2020;7:611-27.

6. O'Donoghue B, Lyne J, Madigan K, Lane A, Turner N, O'Callaghan $\mathrm{E}$, et al. Environmental factors and the age at onset in first episode psychosis. Schizophr Res. 2015;168:106-12.

7. Fusar-Poli P, Cappucciati M, Bonoldi I, Christy Hui LM, Rutigliano G, Stahl DR, et al. Prognosis of brief psychotic episodes a metaanalysis. JAMA Psychiatry. 2016;73:211-20.

\section{Correspondence:}

Ary Gadelha

Laboratório Interdisciplinar de Neurociências Clínicas (LiNC)

Departamento de Psiquiatria

Escola Paulista de Medicina - Universidade Federal de São Paulo (EPM-UNIFESP)

Rua Pedro de Toledo, 669, 30 andar

05039-032, São Paulo, SP - Brasil

E-mail: aryararipe@gmail.com 